\title{
Investigating the Perception of Indonesian Tertiary Students Toward the Use of Schoology as Supplementary Vocabulary Teaching Platform
}

\author{
Imelda Gozali, B.Eng., M.Pd \\ English Education Department, Faculty of Teacher Training and Education \\ Universitas Katolik Widya Mandala Surabaya \\ Surabaya, Indonesia \\ Imelda.gozali@ukwms.ac.id
}

\begin{abstract}
Digital literacy is undoubtedly the byword of $21^{\text {st }}$ century skill to be acquired by the students, as well as to be promoted and implemented by teachers and institutions all over the world. The field of English Language Teaching is not exempted from the onslaught of technology either. Teachers are expected to incorporate technology in and outside the classroom, be it to cater to the learning needs of the digital natives, or simply to comply with institutional demands. In line with this rapid technological development, there is a proliferation of Learning Management Systems (LMS) for English teachers to use and explore. One such LMS, Schoology, has been widely used by the lecturers in the college where the writer teaches. This semester, the writer is experimenting with Schoology to supplement her Vocabulary class. The rationale behind this implementation is the lack of time in the face-to-face meeting, which consists mainly of lecture, discussion and exercises. As such, there is little, if any, time for real usage of the vocabulary learned. The writer then made use of the Discussion feature in Schoology to create an online discussion where the students answer a question related to the Vocabulary item, and can comment on their friends' answers. In this study, the writer is interested to investigate the perception of her students on the use of Schoology as the supplementary platform for teaching and learning vocabulary, specifically to know their opinion on the effectiveness of using Schoology to enhance their vocabulary usage and retention.
\end{abstract}

Keywords: Learning Management System (LMS), Schoology, vocabulary, Indonesian tertiary students

\section{INTRODUCTION}

As trite as it may sound, the Industrial Revolution 4.0 has brought many consequences in its wake, not less in the field of education. Both students and teachers alike are expected to be digitally literate; a natural trait perhaps for the students, but an (arduously) acquired one for the teachers who don't belong to the millennial generation. While students surf, click, and navigate the vast technological platforms with ease, their educators need to learn how to delve into the ocean of online this and interactive that, in order to bring knowledge to the millennials. It is then of no surprise that the government in this country, in particular the ministry of education and culture, has mandated that one of the basic competencies that teachers must possess is to "utilize information technology and communication to carry out instructional and developmental activities" (National Ministerial Regulation no.16, 2007). In line with this effort, there is no lack of seminars and training for teachers in the field of ICT (Information and Communication Technology), which is backed up by a plethora of studies that support the benefits of its use in imparting and acquisition of knowledge to and by the students respectively (Livingstone, 2012; Wheeler et. al., 2005; Wong, 2016; etc.). The widespread use of such technology in the classroom has given birth to the pedagogical strategy termed blended learning, which combines the orthodox way of face-to-face meeting in the classroom with virtual lessons through online media (Garrison and Kanuka, 2004)

In response to the demand for educational platform based on Web 2.0 which allows for greater interactivity between the users, many IT companies have come up with various Learning Management System (LMS) products such as Schoology, Edmodo, and Moodle to name a few. Numerous studies have been conducted on the application of such LMS for language teaching and learning, as well as the tangible benefit of using such platforms (Cavus et al, 2007; Basal, 2015; etc). Schoology for example, has been used with positive outcome as the blended learning media for teaching English for Academic Purpose (Ardi, 2017), writing (Cahyaningrum, 2017), reading (Widhiatama, 2016), and many more.

Partly as a means of compliance to the government regulation as stated above, and partly being convinced of the benefit of incorporating technology into the classroom, the tertiary institution where the writer is working has encouraged all the teachers to use LMS, in particular Schoology, as part of their teaching strategy and method. In-house trainings have been conducted and some of the best practices shown. For some years now, Schoology has been used by the lecturers of the 
institution especially for teaching reading and writing. As regards the perception of the students on the use of Schoology, there were mixed reactions among them as obtained from casual conversation with the students; some have no qualms about using Schoology, while others find it difficult and burdensome.

Having to teach a new course this year which is Vocabulary $\mathrm{B}$, the writer is intrigued to experiment with using Schoology to supplement the Vocabulary B lessons. The rationale behind this implementation is the lack of time in the face-to-face meeting, which consists mainly of lecture, discussion and exercises. As such, there is little, if any, time for real usage of the vocabulary learned. Therefore, she made use of the Discussion feature of Schoology to make question prompts for her students related to the Vocabulary topic being taught, so that the students can create sentences and statement on that topic using the vocabulary learned. In order to gauge the effectiveness of this technological implementation, as well as to find its acceptance among the students, this study was carried out to find out the perception of the students on the use of such platform for their learning and retention of the vocabulary taught.

\section{A. Schoology}

Within the gamut of social networking sites, Schoology is one that specializes in the field of education, providing the media for teachers and students to interact online through shared materials and resources. With features such as Courses and Grades, teachers are able to create a virtual classroom for their course to which the students join by giving them an access code. Within the Course, teachers can upload their teaching materials, create quizzes, or start an online discussion forum. There is also a Grades feature wherein the students' quiz or test results can be displayed and managed. On their part, students can access the materials at their own time and pace, as well as do the online tests or take part in the discussion forum. Thus, Schoology seems to conform to the purported unique benefits of mobile social media learning identified by UNESCO (2013) such as "facilitating personalized learning, providing immediate feedback and assessment, ... enabling anytime, anywhere learning" (cited in Cochrane and Narayan, 2016)

In the field of English Language Teaching (ELT), Schoology has been widely used for teaching and learning various English language skills and components with reported success. Although the context was Blended Learning, the use of Schoology was perceived as helpful to improve in the study of English Vocabulary and Listening skill as compared to other aspects such as Speaking and Writing (Yagci et. al., 2016). Schoology was also found to enhance the performance of college students taking Business Writing, although caution was given that it should only supplement the class since students still show preference to face-to-face meeting (Sicat, 2015). Another study conducted in China showed the positive effect of using the Flipped Classroom method, with Schoology being used as the online media, on the Vocabulary and Listening skill of the students, since it enhances students' autonomy in learning (Yang and Lee, 2018).

Schoology is also a popular LMS for English teachers in Indonesia, as evidenced by the numerous studies on this subject.
Widhiatama, for example, designed a supplementary reading materials for a Reading course using most of the features available in Schoology, coupled with the guiding principles of incorporating LMS into the syllabus (2016). His design is truly worth noting for teachers in this field. The Discussion feature of Schoology has also been taken advantage of for giving online peer review for a Writing class (Zainuri and Cahyaningrum, 2017). The authors claimed that Schoology was able to increase engagement among the students and help them to think critically as they gave feedback on their friends' writing. Even in the area of Pronunciation, Schoology was shown to fulfill the three criteria of pedagogy as expounded by Plato (cited in Roth, 2009), namely that it be interactive, personalized, and holistic (Margetan, 2016). Another study sought to find the students' perception of their own engagement and improvement in a Speaking class which uses Schoology as the media for a Flipped Classroom method (Ginola and Sidabalok, 2016). The study reported positive outcome in those two aspects.

\section{B. Vocabulary Teaching and Learning}

The belief that Vocabulary should be taught as a separate subject, as opposed to being taught together with Reading skill or Grammar lesson for example, seems to be already widely accepted (Channell, 1988). At the same time, there is also an agreement among scholars that Vocabulary should not merely be taught through rote-learning and memorizing, but also embedded within communicative activities. It was also suggested that Vocabulary teaching method should encompass both its static element (the semantic or meaning of the word) and dynamic (its usage) part (Carter, 1992). Hence, it is of paramount importance that students learn the meaning of the words, as well as be able to use the words in context (Allen, 1983; DeCarrico, 2001). Taylor (1990) proposed that, in order not to overwhelm students with learning both the meaning and the context at the same time, they should first learn the meaning through drilling or repetition, and then practice the words learned in context.

$\mathrm{Gu}$ and Johnson (1996) conducted a thorough and comprehensive studies on the belief of Chinese students regarding the studies of Vocabulary, as well as the strategies they employ when learning Vocabulary. The results showed that, together with other techniques such as contextual guessing and skillful use of vocabulary, intentional activation of new words had a positive correlation with both vocabulary size and English proficiency of the students. This means that students who try to apply the vocabulary learned into practice, be it in their writing or conversation, will most likely to succeed in increasing their vocabulary size and improving their overall English skill. This study goes on to show once more the importance of using the words learned in context for its retention and future application.

\section{METHOD}

This study is a qualitative one, employing a questionnaire as its main instrument. The participants of this study is an intact class consisting of 17 tertiary students who were taking Vocabulary B as one of their subjects for the semester. The data analyzed were the responses of the students to the questionnaires. The textbook used for the course was "English 
Vocabulary in Use" by Michael McCarthy and Felicity O'Dell, published by Cambridge University Press. The syllabus of the course prescribes two units of the book being covered for each meeting, which consists of 2 (two) credit units. By way of examples, some of the Vocabulary items that the students should master in this course include Simile ("as blind as a bat", "as thin as a rake" ...), Idiom ("over the moon", "pain in the neck" ...) and Idiom Connected with Praise/Criticism ("out of this world", "take the biscuit" ...).

The use of Schoology to supplement the lessons was carried out at the middle of the semester, i.e. after the students had taken their mid-term examination. After each class, that is, after two units have been covered, the writer created a Discussion topic in Schoology related to the Vocabulary items that were recently discussed. For example, after covering the unit about Simile, a Discussion thread was created with the following prompt: "Describe yourself or someone you know using the Simile from this unit, together with the reason for using the Simile." An example was also given for clarification, like "When I take off my glasses, I am as blind as a bat." A screenshot of the variety of Discussion topics and their prompts are shown here as Figure 1.

FIGURE 1: PROMPTS FOR DISCUSSION IN SCHOOLOGY

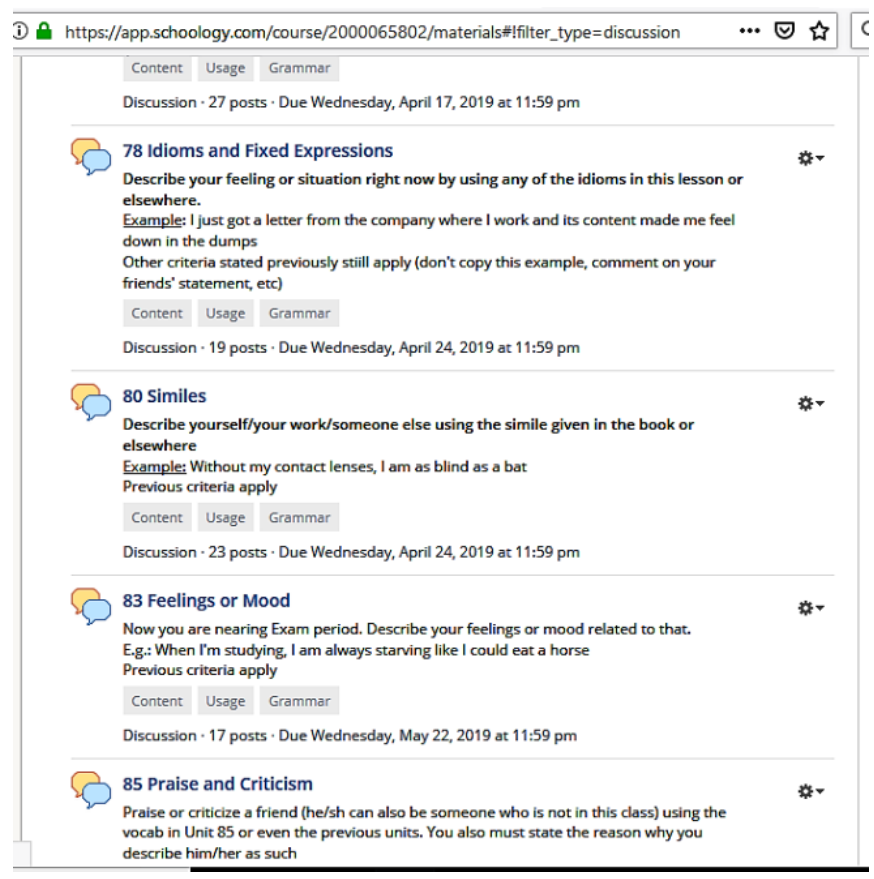

The students then posted their sentences on the space provided, and they were also able to see their friends' posts and comment on them. The writer, who is also their lecturer, then gave a score for the postings, based on a rubric assessing the application of the vocabulary, accuracy of usage, and grammatical correctness. The writer also gave comments, when necessary, to explain the score given. A screenshot of a sample of the discussion thread, showing comments from peers and teacher, is shown below as Figure 2. This exercise, which was given to the students as part of their Assignment score, continued until a total of 8 (eight) Discussion topics.
FIGURE 2: DISCUSSION THREAD WITH POSTINGS AND COMMENTS

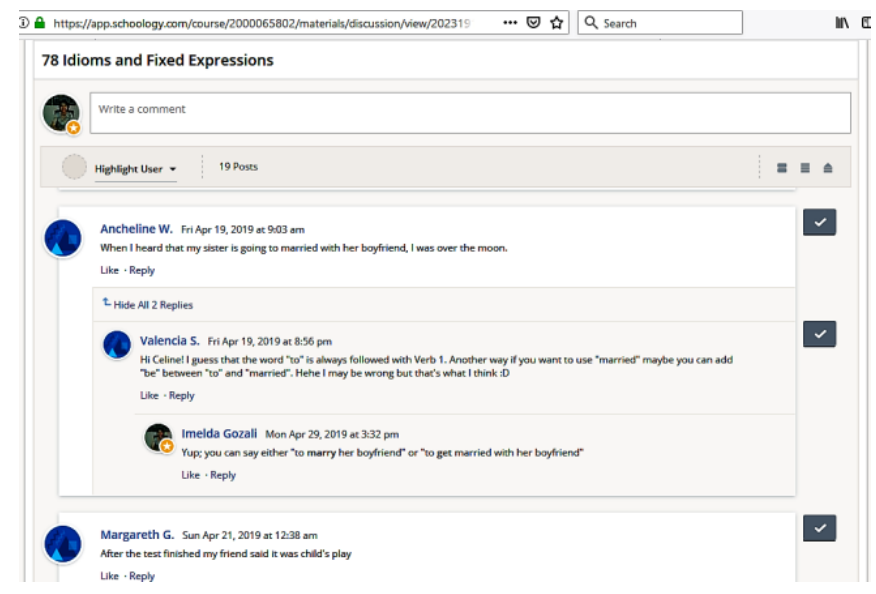

At the end of the course, a questionnaire was administered to the student, which they filled up in an anonymous manner. They were also duly informed that the result of the questionnaire will be used solely for research purpose. The questionnaire consisted of 2 (two) parts; one was a Likert scale type with 10 (ten) questions given in English, with a scale of 1 (one) to 4 (four) ranging from Strongly Disagree to Strongly Agree, without the Neutral response. The second part of the Questionnaire is given in Bahasa Indonesia, to facilitate the students' free expressions, and is made up of 5 (five) questions of mixed response type, such as multiple choice with short explanation, or yes/no questions with request for reasons.

\section{FINDINGS AND DISCUSSION}

The result of the questionnaire was tabulated and analyzed, and the more salient findings are discussed here. The first question asked them whether it was easy to use Schoology in this subject. Here, eight (8) students responded Agree and seven (7) Strongly Agree. In the next questions, they were asked if they can learn about the Vocabulary taught by using it in their sentence postings. For this question, 11 responded Agree and six Strongly Agree. Another question asked if they could learn more about the Vocabulary items from their friends' postings. Here, the majority (12 students) chose Agree and four students picked Strongly Agree. Therefore, it can be concluded that all students were in agreement, and some strongly so, that they were able to consolidate their Vocabulary learning through the sentence postings, be them their own or their friends'.

There were also questions related to the Comments that their friends and lecturer made on their postings, and whether they were able to learn about Vocabulary, or other aspects of English language, from the comments. As can be seen from the sample Discussion thread in Figure 2, a friend reminded the one posting that "to" is followed by Verb1, so the comments were not always related to vocabulary. Again, when asked about learning from their friends' comments, the majority (71\%) answered Agree and the remaining 29\% answered Strongly Agree. For the teachers' comments, there were equal number of students (eight) answering Agree and Strongly Agree, with only one student responded with Disagree. Therefore, again generally speaking the students were also able to gain some insight about 
the Vocabulary taught, or even about grammar and other linguistic aspects, from the comments of their peers and teacher.

The last question of the Likert scale type asked them whether they would suggest that Schoology be used for future Vocabulary course. 76\% of the students put Agree and the rest Strongly Agree. A summary of the all the Likert scale questionnaire results is depicted below as Figure 3.

FIGURE 3: SUMMARY OF THE QUESTIONNAIRE'S RESULTS

\begin{tabular}{|c|c|c|c|c|c|}
\hline No. & Questions & 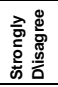 & 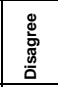 & 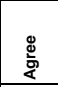 & 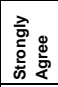 \\
\hline 1 & $\begin{array}{l}\text { It is easy to use Schoology in this course (in terms of } \\
\text { accessing the web, posting the answers, commenting, } \\
\text { monitoring grades) }\end{array}$ & $0 \%$ & $0 \%$ & $53 \%$ & $47 \%$ \\
\hline 2 & $\begin{array}{l}\text { I always post my sentence in each topic of the Discussion } \\
\text { Page }\end{array}$ & $0 \%$ & $18 \%$ & $59 \%$ & $24 \%$ \\
\hline 3 & I find the topics interesting & $0 \%$ & $12 \%$ & $53 \%$ & $35 \%$ \\
\hline 4 & $\begin{array}{l}\text { I can learn to apply the vocabulary taught by using it in my } \\
\text { sentence postings }\end{array}$ & $0 \%$ & $0 \%$ & $65 \%$ & $35 \%$ \\
\hline 5 & $\begin{array}{l}\text { I can learn more about the vocabulary taught from my } \\
\text { friends' posting }\end{array}$ & $0 \%$ & $0 \%$ & $71 \%$ & $24 \%$ \\
\hline 6 & $\begin{array}{l}\text { I can learn more about any aspect of English learning from } \\
\text { my friends' comments (on my or others' postings) }\end{array}$ & $0 \%$ & $0 \%$ & $71 \%$ & $29 \%$ \\
\hline 7 & $\begin{array}{l}\text { I can learn more about any aspect of English learning from } \\
\text { my teachers' comments (on my or others' postings) }\end{array}$ & $0 \%$ & $6 \%$ & $47 \%$ & $47 \%$ \\
\hline 8 & I think the grades that I receive for my postings are fair & $0 \%$ & $12 \%$ & $53 \%$ & $35 \%$ \\
\hline 9 & $\begin{array}{l}\text { I can get to know my classmates better through the } \\
\text { sentence postings }\end{array}$ & $0 \%$ & $29 \%$ & $53 \%$ & $18 \%$ \\
\hline 10 & $\begin{array}{l}\text { I suggest that Schoology be used for future Vocabulary } \\
\text { course }\end{array}$ & $0 \%$ & $0 \%$ & $76 \%$ & $24 \%$ \\
\hline
\end{tabular}

Lastly, the second part of the questionnaire contains openended questions like whether or not they like using Schoology in this course and the reason why. The majority of the students (15 students or $88 \%$ ) replied in the positive, stating reasons such as ease of use, the need to boost grades, as well as being able to apply the vocabulary learned in sentences. Students who disagreed stated that there was no reminder or alert for the task and he/she couldn't cope with it due to other assignments. Another question asked why, if ever, the students did not post their sentences on Schoology. The replies ranged from technical constraints (internet connection, laptop/hand phone problem), forgetfulness, being embarrassed, or not knowing how to answer.

From the result of the questionnaire above, it could be concluded in general that all the students have positive perception of the use of Schoology as the supplementary teaching platform for Vocabulary B course. They perceived that the Discussion feature of Schoology helped them to recall and apply the Vocabulary learned in the previous lessons, through the sentences that they posted. They were also of the opinion that they could learn from the comments to their postings, both by their peers and teacher. The perceived benefit of using Schoology might have prompted them to agree, be it moderately or strongly, that it be used for future Vocabulary courses. It was also confirmed, through the Likert scale question and the open-ended one, that the use of Schoology in the way described in this paper didn't seem to be burdensome to the students; they found it easy, fun, and practical. The comment from the students who said that there was no alert to remind them to do the task is a good feedback to the writer to improve the future feature of the Schoology Course for this subject.

The perceived benefit of making sentences containing the Vocabulary learned in Schoology for its usage and retention once again underlines the importance of immediately using the studied words in context, as well as 'activating' the lexicon learned intentionally, as per the previously-cited studies above (Allen, 1983; DeCarrico, 2001; Gu and Johnson, 1996). One of the students wrote the following, "I can learn to use the Vocabulary taught in the form of sentences, and it facilitates me to remember and apply those vocabularies." The interactive feature of Schoology might have also contributed to the positive perception of the students on learning from their friends' postings, as well as from comments of their peers and teacher. To cite one of the long answers of the student, he/she wrote that "I find it exciting to write my sentences and I'm looking forward to see the response from my friends." This is in line with the finding of Zainuri and Cahyaningrum (2017) cited above, about the effect of Schoology on students' engagement and critical thinking, as well as the cited benefits of online media learning by UNESCO (cited in Cochrane and Narayan, 2016) with regards to providing immediate feedback and assessment. Nevertheless, it is recommended that Schoology be used in a supplemental manner, with greater emphasis be placed on face-to-face meeting since not all students are entirely open to the use of Schoology, be it due to technical or psychological constraints as described in the preceding paragraphs. This supports the finding of Sicat (2015) who reported that students still need direct assistance from the instructor and prefer traditional method of instruction.

\section{CONCLUSION}

It could be concluded from this short and simple study that Schoology could be used in the manner described in this article to supplement Vocabulary teaching and learning activities in the classroom, since students generally perceive it as beneficial for Vocabulary application and retention.

However, positive perception alone is insufficient, though it is a start, to prove the effectiveness of using Schoology for Vocabulary classes. Perhaps future, more quantitative studies could be conducted to support this perception, with pre-test, post-test, control and experimental group in the research method.

\section{REFERENCES}

[1] Allen, V. F. (1983) Techniques in teaching vocabulary (New York, Oxford University Press).

[2] Priyatno, A. (2017). Promoting learner autonomy through schoology mlearning platform in an EAP class at an Indonesian University. Teaching English with Technology, 17(2), 55-76. 
[14] No, Permendiknas. (16). Tahun 2007 tentang Kualifikasi dan Kompetensi Guru.

[15] Roth, A. D. Plato's Educational Foundations and the Future of College Teaching.

[16] Sicat, A. S. (2015). Enhancing college students' proficiency in business writing via schoology. International Journal of Education and Research, 3(1), 159-178.

[17] Taylor, L. (1990) Teaching and learning vocabulary (Upper Saddle River, NJ, Prentice Hall).

[18] Wheeler, S., Kelly, P., \& Gale, K. (2005). The influence of online problem-based learning on teachers' professional practice and identity. ALT-J, 13(2), 125-137.

[19] Widhiatama, D. A. (2016). Designing supplementary reading materials for mid beginner students using Schoology (Doctoral dissertation, SANATA DHARMA UNIVERSITY).

[20] Wong, G. K. (2016). A new wave of innovation using mobile learning analytics for flipped classroom. In Mobile Learning Design (pp. 189-218). Springer, Singapore.

[21] Yağcı, H., Çinarbaş, H. İ., \& Hoş, R. (2016). Turkish EFL students' perceptions about blended English courses in a teacher education program. International Journal of Social Sciences and Education Research, 2(3), 959-972.

[22] Yang, Z., \& Lee, C. I. (2018). The Effects of Flipped Vocabulary Learning on Chinese College Students' Listening Achievement. Multimedia-Assisted Language Learning, 21(1), 133-152.

[23] Zainnuri, H., \& Cahyaningrum, D. (2017, October). Using Online Peer Review through Discussion via Schoology to Enhance College Students' Proficiency in Argumentative Writing: A Case Study. In International Conference on Teacher Training and Education 2017 (ICTTE 2017). Atlantis Press.

[13] Margetan, V. (2016). Pedagogical Aspects of Using Schoology in Pronunciation Classes (Doctoral dissertation, Program Studi Pendidikan Bahasa Inggris FBS-UKSW). 